Article

\title{
Sustainable Education Using New Communication Technology: Assessment with Analytical Hierarchy Process (AHP)
}

\author{
Xin-Yu Wang ${ }^{1}$, Guang Li ${ }^{1}$, Jih-Fu Tu ${ }^{2}$, Nguyen Thi To Khuyen ${ }^{3}{ }^{(D)}$ and Chun-Yen Chang ${ }^{3,4, *(1)}$ \\ 1 Faculty of Education, Northeast Normal University, Changchun 130024, China; wangxy446@163.com \\ (X.-Y.W.); lig893@nenu.edu.cn (G.L.) \\ 2 Department of Electrical Engineering, Lunghwa University of Science and Technology, Taoyuan City 333, \\ Taiwan; tujihfu@gmail.com \\ 3 Graduate Institute of Science Education, National Taiwan Normal University, Taipei City 106, Taiwan; \\ ntkhuyen.aliza.231@gmail.com \\ 4 Science Education Center, Department of Earth Sciences, National Taiwan Normal \\ University, Taipei City 106, Taiwan \\ * Correspondence: changcy@ntnu.edu.tw
}

Citation: Wang, X.-Y.; Li, G.; Tu, J.-F.;

Nguyen, K.T.T.; Chang, C.-Y.

Sustainable Education Using New

Communication Technology:

Assessment with Analytical

Hierarchy Process (AHP).

Sustainability 2021, 13, 9640. https://

doi.org/10.3390/su13179640

Academic Editor: Po-Sheng Chiu

Received: 20 June 2021

Accepted: 31 July 2021

Published: 27 August 2021

Publisher's Note: MDPI stays neutral with regard to jurisdictional claims in published maps and institutional affiliations.

Copyright: (c) 2021 by the authors. Licensee MDPI, Basel, Switzerland. This article is an open access article distributed under the terms and conditions of the Creative Commons Attribution (CC BY) license (https:// creativecommons.org/licenses/by/ $4.0 /)$.

\begin{abstract}
This study explores how new communication technology is implemented in education by mainly focusing on the teacher's role. With a questionnaire and interview surveys, the analytic hierarchy process (AHP) was carried out to understand the factors that affect implementing new communication technology in education. New technologies such as the fifth-generation (5G) technology contribute to the realization of ubiquitous and effective learning. Effective adoption of this technology for education is pedagogically based on teachers' capability and determination to improve students' learning activities. The results indicate that teachers and students prefer traditional teaching methods to the new technological methods, with a high weight recorded for the "maintaining the traditional teaching tools" criteria in the solution layer. The importance of the criteria layer shows that there are possibilities of implementing new technologies into education with appropriate support. When considering teachers' effort, time spent, and resources used to prepare adequate materials, teachers are hesitant about using new technology. However, support helps to implement new communication technology successfully into education, especially teaching. Even with the many advantages of new technology, such as 5G, its problems prohibit teachers from actively using new technology. To provide a basic understanding of how to encourage teachers to successfully implement new technology into education, especially teaching, the results of this study help promote the applications used for sustainable education to narrow the educational divide.
\end{abstract}

Keywords: analytic hierarchy process (AHP); fifth-generation technology; education

\section{Introduction}

Teaching requires fast and accurate feedback through interactions. Such interactions among teachers and students demand "all things connected" in on-site or virtual classrooms and need the functionality of teachers. They require teachers to be professional and have the technical abilities indispensable for their competencies, especially when education in schools needs the combination of theory and practice. An appropriate system is required for subjective teaching or learning as each student learns differently, even in the same environment [1,2].

Chang proposed a cloud classroom (CCR) system for a mobile learning project [2,3]. The basic idea of a CCR involves allowing students to respond to their teachers' questions instantly and frequently by using mobile devices that mimic real classrooms. CCRs operate on multiple platforms without being installed on computers. Once teachers connect to their devices, they can easily teach and quiz their students. In addition to the traditional forced-choice format, CCRs allow verbal and visual responses using short texts, pictures, 
or emoticons. Then, students' answers are automatically analyzed in real time so that teachers can monitor their classes' learning progress. The newly developed gamified electronic audience response system (GEARS) allows teachers to post questions and receive students' responses. This additional feature of CCRs turns traditional question and answer sessions into ones in which individuals or groups of students can participate. This enables CCRs to make classroom teaching and learning interactive and enjoyable [1,2]. To use these systems, fast and stable communication is required to enable symmetric education, which is one of the advantages of CCRs. Symmetric education transforms limited learning with scattered knowledge across various fields to unlimited learning with limitless resources and knowledge. The problems of limited learning with scattered knowledge in traditional teaching originate from limitations in time, space, and the availability of various content. A communication network with high speed, low latency, and limitless accessibility is needed to solve such problems, especially for smart classrooms, teaching assistant robots, and notebooks.

Recently developed, fifth-generation (5G) technology possesses the properties to solve these problems-it is characterized by enhanced interactivity, individualization, and diversification. It is mainly used in multimedia communication for industry, academia, and education. Applications of 5G technology primarily focus on using its high data volume, fast data transmission, ability to allow an increased number of connected devices, and low end-to-end latency. However, applying 5G technology to various fields involves the challenge of developing appropriate multimedia content and processing technology, as traditional ones are not appropriate because of their limitations in compression, encoding, transmission, processing, synchronization, storage, and mining of data [4,5].

Students develop physiologically and socially based on biological growth and social structures, respectively. As they develop, students build knowledge through action and reflections with continuous feedback. Thus, teachers need to find appropriate ways and tools to educate students. Especially today, teachers need to be accustomed to using new technology. The use of technology makes learning unlimited in time and space. Thus, integrating new technology and teaching methods provides teachers with feasible and highly useful educational tools.

Thus, this study aims to determine how new communication technology (5G) can enhance teaching by evaluating teachers' ability and acceptance of using this technology. It is also necessary to explore how the relationships between teachers' and students' satisfaction and attitudes toward technology affect teaching and learning. Therefore, the results of this study provide guidance on how to use technology to introduce new teaching methods into classrooms; this new technology can be used for sustainable education, which lessens the differences between urban and rural schools. The study also provides basic suggestions on how to implement this new technology into educational settings. The study's conclusion contributes to defining the role of teachers in the coming new technology era.

\section{Methods}

\subsection{Pre-Survey and Interview for Creating Questionnaire}

A survey was carried out to define the factors affecting students' satisfaction, attitudes, behaviors, feelings, and achievements in learning and then determine the level of teachers' acquisition of and students' satisfaction with learning resources. We interviewed six students before drafting a questionnaire; three majored in non-information-related and three in information-related studies. Five teachers in Taiwan (one teacher) and China (four teachers) were interviewed through video conferencing. The interview result was utilized to define factors in learning satisfaction, including curriculum arrangements, teaching, learning environment, and learning outcomes related to learning satisfaction and attitudes. The questionnaire included 48 questions in 7 categories (Table 1). The questionnaire survey was carried out from 17 May to 18 June 2019 for teachers and students of the middle school of the Northeast Normal University, Changchun. There were 23 uncompleted and 196 valid questionnaires, with a recovery ratio of $89.5 \%$. 
Table 1. The questions in the questionnaire for this study.

Category

I. The learning attitudes of students in professional computer license courses by different background knowledge.

II. The emotional part of the learning attitudes of students in professional computer license courses by personal background.

III. The learning behaviors of students in professional computer license courses by personal background.

IV. The difficulty of students in learning in professional computer license courses by personal background.

V. The learning satisfaction of students in professional computer license courses by personal background.

VI. Student's satisfaction and learning attitude in computer professional license courses.

VII. Student's satisfaction and learning difficulty in computer professional license courses.

\section{Questions}

There is a gender difference in student's learning attitudes by background knowledge.

There is an age difference in student's learning attitudes by background knowledge.

Student's learning attitude varies in different subjects by background knowledge.

Student's learning attitude varies by the different employment prospects.

Student's learning attitude varies by the number of possessed licenses. Student's learning attitude varies by practice hours.

There is a gender difference in the emotional part of the learning attitude.

There is an age difference in the emotional part of the learning attitude.

Student's emotions and learning attitudes vary in different subjects.

Student's emotions and learning attitudes vary by the different employment prospects.

Student's emotions and learning attitudes vary by the number of possessed licenses.

Student's emotions and learning attitudes vary by the practice hours.

There is a gender difference in the learning behaviors of the students.

There is an age difference in the learning behaviors of the students.

Student's learning behavior varies in different subjects.

Student's learning behavior varies by the different employment prospects.

Student's learning behavior varies by the number of licenses possessed by the student.

Student's learning behavior varies by practice hours.

There is a gender difference in the learning difficulty of students.

There is an age difference in the learning difficulty of students.

Student's learning difficulty varies in different subjects.

Student's learning difficulty varies by the different employment prospects.

Student's learning difficulty varies by the number of licenses possessed by the student.

Student's learning difficulty varies by the practice hours.

There is a gender difference in the learning satisfaction of students.

There is an age difference in the learning satisfaction of students.

Student's learning satisfaction varies in different subjects.

Student's learning satisfaction varies by the different employment prospects.

Student's learning satisfaction varies by the number of licenses possessed by the student.

Student's learning satisfaction by practice hours.

There is a significant difference in students' understanding and the course design.

There is a significant difference between students' understanding and teaching.

The learning environment affects student's understanding and achievement in learning.

Learning satisfaction affects the learning performance and understanding of students.

Learning satisfaction affects student's emotions and learning satisfaction.

The learning environment affects student's emotions and learning satisfaction.

Learning satisfaction affects student's behavior and course design.

Learning satisfaction affects student's behavior and teaching.

Learning satisfaction affects student's behavior in the learning environment.

The learning environment affects student's understanding and achievement in learning

The curriculum design affects student's learning difficulties and learning satisfaction.

Teaching affects student's learning difficulties and learning satisfaction.

The learning environment affects student's learning difficulties and learning satisfaction.

The achievement in learning affects student's learning difficulties and learning satisfaction.

The survey data were analyzed to define the target, criteria, and solution layers to find their significance and establish a hierarchical architecture. After the hierarchy was established, the relative importance of each factor in each layer was defined. Then, an analytic hierarchy process (AHP) was adopted by using pair-wise comparison. 


\subsection{Elements for Hierarchical Structure}

Learning is a conversation and interaction between teachers and students in a learning environment. Subjective learning focuses on the development and uniqueness of each student. For student-centered teaching, subjective learning needs a root structure that is not centralized and formalized [3].

\subsubsection{Students}

Students tend to assimilate the characteristic of their groups even though each student has a personality. In schools, students depend on the embodiment of this commonality for learning. However, students prefer subjective learning as they translate the learning content with their ways of thinking. The environmental system theory [6] illustrates the importance of the environment for teaching or learning. Individual development is nested in interlinked environmental systems in which individuals interact and realize individual development. The Internet of Things (IoT) and 5G technology greatly expand teachers' classroom abilities and allow them to focus more on students than ever before [7]. They help teachers regard each student as the basic unit of education, as an individual, and cultivate their talents and responsibility.

\subsubsection{Teachers}

Teachers have a great impact on students by maintaining bi-directional relationships. Thus, the personality and ability of teachers and students affect their behaviors [8,9]. The teacher's purpose of teaching in a learning environment is to promote students' individual development. For this, teachers need to have specific knowledge to lead students to learn. Nowadays, teachers need to mediate between students and technology and learn the necessary technology to create new environments, methods, and materials and enhance students' growth, performance, and learning satisfaction [10].

\subsubsection{Relationship between Learning and Teaching}

Schools need to build a new concept of learning with the convenience, immediacy, and sharing of educational resources in the 5G technology era. This requires reconstructing schools and establishing a national educational resource center and a learning databank of high quality. Removing the barriers among schools, schools, and social education institutions and families is inevitable for learning with the new concept. Building a new concept of learning demands reforming the educational structure and establishing a future-oriented educational model in a new educational ecosystem using modern technologies such as the $5 \mathrm{G}$, big data, and artificial intelligence (AI). The role of teachers is important in leading the efforts to form a community of teachers and students in which a mutual understanding of teacher and student is essential for bond and harmony [11]. This relationship is based on interpersonal communication through teaching with learning technologies [12].

\subsubsection{Teacher: Intermediary between Students and Technology}

Though the technological revolution has reformed education in various ways, the important task of teachers is always to provide appropriate learning for students. To this end, 5G technology accelerates the revolution in learning technology due to its use of the internet and e-learning platforms [5]. It reduces the cost of knowledge and provides unlimited information stored in various media [13]. Thus, teachers need to be an intermediary between students, knowledge, and technology. As an intermediary, teachers need to avoid influencing students with their personalities to maintain students' subjective learning. Teachers must make extra efforts to teaching effectively with suitable technology.

\subsubsection{Learning Satisfaction}

Since the 1960s, when computers appeared for the first time, scholars have tried to replace human teaching with machine teaching, and some proposed the theory of "school demise." Later, the internet changed the traditional educational structure. Recently, teach- 
ers use various media with $5 \mathrm{G}$ technology and create a balanced role between providing materials and effective teaching [14]. Appropriate teaching materials and their use for effective teaching are critical to improving students' learning behaviors and satisfaction [15]. For learning satisfaction, the role of teachers as intermediaries becomes more important than ever before [16]. The difficulty and complexity during the development of students may cause problems more than technology, which requires teachers to be the intermediary between students and technology. The relationship between teacher, students, and technology is presented in Figure 1.

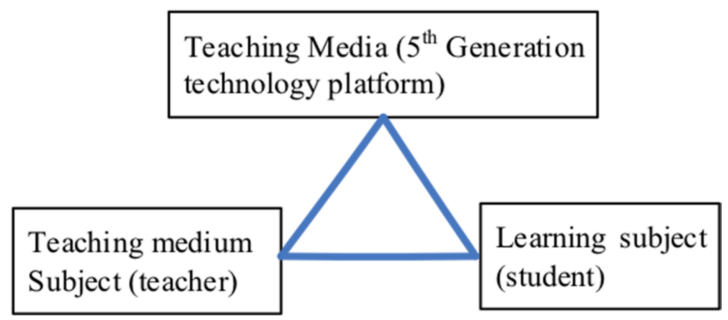

Figure 1. Teacher as an intermediary under the framework of $5 \mathrm{G}$ technology.

\subsection{Analytic Hierarchy Process (AHP)}

The analytic hierarchy process (AHP) was developed by Saaty [17]. Although AHP has been shown to have several problems, it has been widely used to select the best alternatives from plausible ones and choose the appropriate decision-making process by establishing weights and criteria in education [18-20]. Therefore, the selected AHP research method was used in the problem analysis in this study. It was developed to solve decisionmaking problems and obtain criteria for the evaluation of planning, decision making, and performance. Saaty proposed AHP for planning, alternative decision, prioritizing, resource allocation, risk assessment, system design, performance measurement, system stability, optimization, conflict resolution, decision making, and politics. AHP is mainly used to analyze problems or systems that have interactions at different levels. AHP decomposes the elements that affect a system into several groups and builds a hierarchical structure. The factors mentioned above are included in the questionnaire survey, and based on the result, an AHP was established.

\section{Results}

\subsection{Questionnaire Survey Result}

The survey was carried out from 17 May to 18 June 2019. The Cronbach $\alpha$ values higher than 0.755 showed that the questionnaire was well designed and organized with significant internal consistency and reliability (Table 2).

Table 2. The internal consistency and reliability of the questionnaire survey result by Cronbach $\alpha$.

\begin{tabular}{ccc}
\hline Category & Number of Questions & Cronbach $\alpha$ \\
\hline I & 6 & 0.877 \\
\hline II & 6 & 0.805 \\
\hline III & 6 & 0.871 \\
\hline IV & 6 & 0.887 \\
\hline V & 6 & 0.755 \\
\hline VI & 12 & 0.929 \\
\hline VII & 4 & 0.850 \\
\hline Overall reliability & 48 & 0.898 \\
\hline
\end{tabular}




\subsection{Establishment of $A H P$}

We established the AHP hierarchy, as shown in Figure 2. We defined "teacher as the intermediary between students and technology" as the main factor in the target layer with two sub-factors such as "choose and combine new technology" and "maintain traditional teaching method" according to the purpose of this study. In the criteria layer, eight factors were defined, as explained in Table 3. The factors mainly address how to encourage and support teachers in the implementation of the new technology. They are grouped according to teachers' efforts for using the technology ("teacher experience and sense of accomplishment"; "investing in innovative teaching"; "understanding technology"), incentives ("incentive"; "promotion"), school's support ("school's service"; "school's support"), and interaction with students ("interaction time with technology according to the main factor"). In the solution area, "new technology and platform" and "traditional teaching tools" are defined as plausible solutions for the AHP analysis.

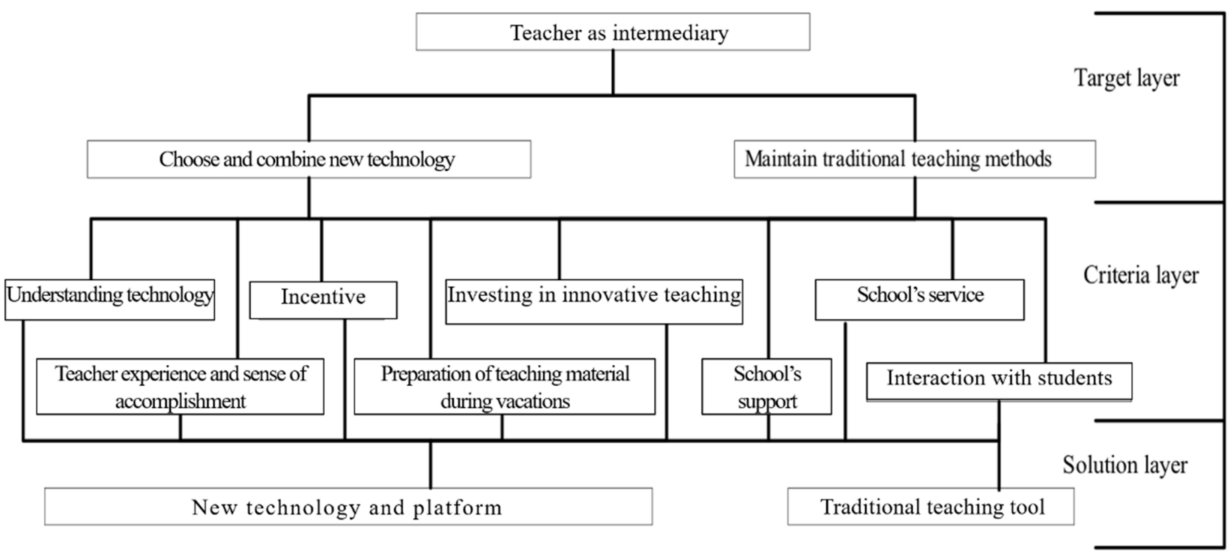

Figure 2. The hierarchical analysis for teacher's roles in teaching with recent technology.

Table 3. The factors and their description in the criteria.

\begin{tabular}{cc}
\hline Factor & Description \\
\hline $\begin{array}{c}\text { Teacher experience and sense of } \\
\text { accomplishment }\end{array}$ & $\begin{array}{c}\text { Teacher's experience and a sense of } \\
\text { accomplishment in investing in innovative } \\
\text { teaching. }\end{array}$ \\
\hline Investing in innovative teaching & $\begin{array}{c}\text { Teachers invest time and resource in } \\
\text { innovative teaching to reduce the number of } \\
\text { teaching hours. }\end{array}$ \\
\hline Incentive & $\begin{array}{c}\text { Subsidies such as vacation, overtime pay, and } \\
\text { bonuses for investing in innovative teaching. }\end{array}$ \\
\hline School's service & $\begin{array}{c}\text { Teachers' understanding and understanding of } \\
\text { the communication technology and } \\
\text { applications. }\end{array}$ \\
\hline School's support & $\begin{array}{c}\text { The service qualifications of the school are } \\
\text { innovative intentions for innovative teaching. }\end{array}$ \\
\hline Interaction with students & $\begin{array}{c}\text { School provides teachers with innovative } \\
\text { teaching methods and changes in teaching } \\
\text { materials. }\end{array}$ \\
\hline vachations & $\begin{array}{c}\text { Questions are asked by students and the } \\
\text { circumstances under which they are solved. }\end{array}$ \\
\hline $\begin{array}{c}\text { During each year's winter and summer } \\
\text { vacations, teachers make full use of the holiday } \\
\text { to prepare teaching materials. }\end{array}$ \\
\hline
\end{tabular}


According to the hierarchy, we tested the target, criteria, and solution layer factors and present them in the following sections.

\subsubsection{Target Layer}

The target layer of the AHP contained two targets of "choose and combine new technology" and "maintain traditional teaching method" to compare the preference of teachers and students. To determine the relative importance of the target layers, we compared them and calculated the consistency index (CI) as follows:

$$
\mathrm{CI}=\frac{\lambda \max -n}{n-1}
$$

where $\lambda_{\max }$ is the maximum score calculated as Equation (2).

$$
\lambda_{\mathrm{m}}=\left(\frac{w_{1}}{w_{1}^{\prime}}+\frac{w_{2}}{w_{2}^{\prime}}+\frac{w_{3}}{w_{3}^{\prime}} \ldots+\frac{w_{n}}{w_{n}^{\prime}}\right)
$$

where $w_{\mathrm{n}}$ is the weight of each factor, and $w_{\mathrm{n}}^{\prime}$ is the weight for its eigenvector. The result is shown in Table 4.

Table 4. RI with different $n$ values.

\begin{tabular}{ccccccccc}
\hline $\boldsymbol{n}$ & $\mathbf{1}$ & $\mathbf{2}$ & $\mathbf{3}$ & $\mathbf{4}$ & $\mathbf{5}$ & $\mathbf{6}$ & $\mathbf{7}$ & $\mathbf{8}$ \\
\hline $\mathrm{RI}$ & 0 & 0 & 0.58 & 0.9 & 1.12 & 1.24 & 1.32 & 1.41 \\
\hline $\boldsymbol{n}$ & $\mathbf{9}$ & $\mathbf{1 0}$ & $\mathbf{1 1}$ & $\mathbf{1 2}$ & $\mathbf{1 3}$ & $\mathbf{1 4}$ & $\mathbf{1 5}$ & \\
\hline $\mathrm{RI}$ & 1.45 & 1.49 & 1.51 & 1.48 & 1.56 & 1.57 & 1.58 & \\
\hline
\end{tabular}

With acceptable consistency, the decision alternatives were sorted within the scope of each factor to establish the priority within the factors. Different $\mathrm{CI}$ values were generated at the different hierarchy levels as the random index (RI) defined in Table 4 [21]. RI is a matrix of values generated by the evaluation scale from 1 to 9 . The RIs generated under different orders $(n)$ are outlined in Table 4.

Then, the ratio of the CI value to the RI value is calculated as the consistency ratio $(\mathrm{CR})[6]$.

$$
\mathrm{CR}=\frac{\mathrm{CI}}{\mathrm{RI}}
$$

The CI, RI, and CR results are shown in Table 5 and imply that the target layer factors have consistency and are randomly selected. The low CRs of the target layer reveals that the respondents replied to the questions consistently.

Table 5. CI, RI, and CR in the target layers. $\left(\lambda_{\max }=3.054, n=3\right)$.

\begin{tabular}{cccc}
\hline Factor & CI & RI & CR \\
\hline $\begin{array}{c}\text { Choose and combine } \\
\text { new technology }\end{array}$ & 0 & 0.58 & 0 \\
\hline $\begin{array}{c}\text { Maintain traditional } \\
\text { teaching method }\end{array}$ & 0.027 & 0.58 & 0.0465 \\
\hline
\end{tabular}

The weights of the two sub-factors ("choose and combine new technology" and "maintain traditional teaching method") are shown in Table 6. The weight of the "maintain traditional teaching method" factor is 0.667 and higher than that of the other factor. This implies that teachers and students prefer to maintain traditional teaching methods. However, when the factor of "teachers as the intermediary between students and technology" is included in the analysis (Table 7), it has the highest weight of 0.413 as the other two factors show 0.260 ("maintain traditional teaching method") and 0.328 ("choose and combine new 
technology"). Tables 5 and 6 indicate that teachers and students still prefer the traditional teaching method, but they also highlight the important role of teachers in introducing recent technology to students.

Table 6. The weights in the target area for two sub-factors.

\begin{tabular}{|c|c|c|c|c|}
\hline Factor & $\begin{array}{l}\text { Choose and } \\
\text { Combine New } \\
\text { Technology }\end{array}$ & $\begin{array}{l}\text { Maintain } \\
\text { Traditional } \\
\text { Teaching } \\
\text { Methods }\end{array}$ & Geometric Mean & Weight (W) \\
\hline $\begin{array}{l}\text { Choose and } \\
\text { combine new } \\
\text { technology }\end{array}$ & 1 & $1 / 2$ & 0.707 & 0.333 \\
\hline $\begin{array}{c}\text { Maintain } \\
\text { traditional } \\
\text { teaching methods }\end{array}$ & 2 & 1 & 1.414 & 0.667 \\
\hline Total & & & 2.121 & 1.000 \\
\hline
\end{tabular}

Table 7. The weights of the target layer including 'Teachers as the intermediary between students and technology'.

\begin{tabular}{|c|c|c|c|c|c|}
\hline Factor & $\begin{array}{c}\text { Teachers as } \\
\text { the } \\
\text { Intermediary }\end{array}$ & $\begin{array}{l}\text { Maintain } \\
\text { Traditional } \\
\text { Teaching } \\
\text { Method }\end{array}$ & $\begin{array}{l}\text { Choose and } \\
\text { Combine New } \\
\text { Technology }\end{array}$ & $\begin{array}{l}\text { Geometric } \\
\text { Mean }\end{array}$ & Weight (W) \\
\hline $\begin{array}{l}\text { Teachers as the } \\
\text { intermediary }\end{array}$ & 1 & 1 & 2 & 1.260 & 0.413 \\
\hline $\begin{array}{l}\text { Maintain } \\
\text { traditional } \\
\text { teaching } \\
\text { method }\end{array}$ & 1 & 1 & 1 & 1.000 & 0.328 \\
\hline $\begin{array}{l}\text { Choose and } \\
\text { combine new } \\
\text { technology }\end{array}$ & $1 / 2$ & 1 & 1 & 0.794 & 0.260 \\
\hline Total & & & & 3.054 & 1.000 \\
\hline
\end{tabular}

\subsubsection{Criteria Layer}

The description of the factors of the criteria layer is shown in Table 8. The weights of "choose and combine new technology" are high for factors including 'teacher experience and sense of accomplishment" (0.667), "incentives" (0.667), "school's service" (0.750), and "school's support" (0.667), and "interaction with technology" (0.667). Other factors such as "investing in innovative teaching," "understanding technology," and "preparation of teaching material during vacations" have weights of 0.500 in terms of the "maintain traditional teaching method" factor. This result shows that supporting teachers and teachers' interaction with students is important to implement the new technology into education. Thus, teachers must be encouraged with incentives and motivated by students' learning attitudes. 
Table 8. The description of the factors and weights in the criteria layer.

\begin{tabular}{ccc}
\hline \multirow{2}{*}{ Factor } & \multicolumn{2}{c}{ Weight } \\
\cline { 2 - 3 } & $\begin{array}{c}\text { Choose and Combine New } \\
\text { Technology }\end{array}$ & $\begin{array}{c}\text { Maintain Traditional Teaching } \\
\text { Method }\end{array}$ \\
\hline $\begin{array}{c}\text { Teacher experience and sense of } \\
\text { accomplishment }\end{array}$ & 0.667 & 0.333 \\
\hline Investing in innovative teaching & 0.500 & 0.500 \\
\hline Incentive & 0.667 & 0.333 \\
\hline Understanding technology & 0.500 & 0.500 \\
\hline School's service & 0.750 & 0.250 \\
\hline School's support & 0.667 & 0.333 \\
\hline Interaction with students & 0.667 & 0.333 \\
\hline $\begin{array}{c}\text { Preparation of teaching material } \\
\text { during vacations }\end{array}$ & 0.500 & 0.500 \\
\hline
\end{tabular}

\subsubsection{Solution Layer}

Table 9 shows the weights of the two factors of the solution layer. The weight of "traditional teaching and platform" is 0.667 , while "new technology and platform" is 0.333 . This implies that teachers and students still regard the traditional teaching methods and tools to be adequate for their teaching and learning even though four factors of the criteria layer indicate that the new technology in education is favorable with proper support for its implementation.

Table 9. The weights of the factors in the solution layer.

\begin{tabular}{ccccc}
\hline s & $\begin{array}{c}\text { New } \\
\text { Technology and } \\
\text { Platform }\end{array}$ & $\begin{array}{c}\text { Traditional } \\
\text { Teaching Tools }\end{array}$ & $\begin{array}{c}\text { Geometric } \\
\text { Mean }\end{array}$ & Weight (W) \\
\hline $\begin{array}{c}\text { New technology } \\
\text { and platform }\end{array}$ & 1 & $1 / 2$ & 0.707 & 0.333 \\
\hline $\begin{array}{c}\text { Traditional } \\
\text { teaching tools }\end{array}$ & 2 & 1 & 1.414 & 0.667 \\
\hline Total & & & 2.121 & 1.000 \\
\hline
\end{tabular}

\section{Discussion}

As described previously, teachers and students still consider traditional teaching methods as appropriate educational tools. In the target layer, three factors describe the role of teachers as intermediaries between students and technology, traditional teaching methods, and new technology (5G technology in this study). The weights reveal that teachers and students still prefer traditional teaching methods to new technology. These findings matched with teacher case studies related to technology-based implementation in [21]. Researchers [21] affirmed that teachers could control classes through traditional ways to enact a technology-based curriculum. However, the weights of the criteria layer show that the possibility of implementing new technology into education with appropriate support and incentives encourages teachers to use new technology. Teachers seem neutral when considering the effort, time, and resources they spend preparing adequate materials and resources. Even though five out of eight factors in the criteria layer show high weights (higher than 0.667), the solution still maintains traditional teaching methods.

This is explained by the disadvantages of new technology, which is the 5G technology in this study, for its implementation in education. The 5G infrastructure is not perfectly implemented yet, even though there have been numerous efforts to use $5 \mathrm{G}$ technology worldwide. Contextual factors are still concerned with applying technology to teaching [22,23], including 5G technology. For example, China and South Korea have built 800,000 and 115,000 5G stations, 
respectively; China has built 5G stations across various countries with more than a few million subscribers. Such a trend is expected to spread to other countries. However, $5 \mathrm{G}$ has a problem using high-frequency millimeter waves that easily interfere with communication, and the transmission distance is short. Only a proper number of base stations achieves enough coverage to provide high speed and low latency with multiple connections. The increased speed and amount of data transmission of the $5 \mathrm{G}$ network contribute to enhancing the performance of the applications in education and especially to remote mobile teaching. Advanced 5G technology allows ubiquitous uses of artificial intelligence (AI), virtual reality (VR), and big data. However, 5G technology still suffers from insufficient infrastructure, high cost, and limited mobile devices with $5 \mathrm{G}$ functions.

Although 5G technology could empower people as a citizen platform, it is situated in a social-technical complex environment, as ecologies with elements such as schools, learners, educators, materials, and content [24]. Even though new communication technology such as $5 \mathrm{G}$ technology changes the way of acquiring knowledge, teachers are the only source of student's learning for the time being. Teachers' professionalism and personal development become the pivotal role for learning. In classrooms, teachers need to act as search engines by connecting students and learning resources. Teachers need to develop their information literacy to become evaluators and facilitators of learning and enable students to change their learning styles and adapt to using digital resources.

In a new teaching platform with the 5G technology, teachers need to change their teaching methods and promote active and deep learning, requiring them to become intermediaries. While traditional communication has dominated in schools, modern communication has mainly been used outside of school. Therefore, teachers face a conflict between the demands for modern and traditional ways of communication, which also demands teachers to serve as an intermediary for mediating the contradiction. The 5G platform of education requires teachers to be active in adopting appropriate technology [8]. Then, teachers need to interact with students and technology, acting as an intermediary for knowledge guidance, value formation, activity organization, and learning feedback. Forming knowledge and values requires social interaction, which necessitates teachers to be important objects of the interaction. Teachers link students to learning resources and guide other teachers.

In emphasizing that learning has no boundaries and no limit in time and space, especially for sustainable education, 5G technology helps to solve the problems that traditional teaching has in simulation and practice teaching and time difference by using artificial intelligence (AI), virtual reality (VR), augmented reality (AR), and the Internet of Things (IoT). However, teachers must develop their ability to independently use 5G technology with the continuing expansion of its infrastructure. Therefore, new ways should be found to encourage and support teachers to learn and use new communication technologies. This is reflected in the AHP analysis result of this study. The problems of new communication technologies such as 5G limit their level of acceptance as alternatives to the traditional teaching methods.

\section{Conclusions}

This study aimed to investigate how new communication technology such as the 5G technology affects teachers and their teaching. For this, an AHP analysis with a questionnaire and interview surveys were carried out. In the hierarchy of the AHP, three factors belong to the target layer: "teacher as the intermediary between students and technology"; "choose and combine new technology"; "maintain traditional teaching method." The criteria layer has eight factors-"teacher experience and sense of accomplishment"; "investing in innovative teaching"; "understanding technology"; "incentive"; "promotion"; "school's service"; "school's support"; "interaction time with technology." In the solution area, "new technology and platform" and "traditional teaching tools" are defined as two factors. The weights of each layer reveal that the traditional teaching methods and tools are preferred to the new technology. This is explained by the weights of the factors of the criteria layer. 
The factors related to support and incentives for teachers who try to adopt the technology in teaching have higher weights than those to efforts and services of teachers. This result indicates that appropriate support is required to successfully implement new communication technologies into education, especially teaching. Even with many advantages of technologies such as $5 \mathrm{G}$, the problems to be solved still prohibit teachers from actively using the technology. For teachers to have a high degree of acceptance for the current $5 \mathrm{G}$ technology, adequate supports are needed. This study provides a basic understanding of what is required to encourage teachers to successfully implement this new technology into education, especially teaching. Considering that the goal of education is to cultivate the ability of students to accept diverse knowledge and technologies, the teacher's role needs to be highly prioritized, especially when implementing new technology. Then, when new technologies such as $5 \mathrm{G}$ or $6 \mathrm{G}$ emerge in the future, the result of this study allows the immediacy of their applications for sustainable education to narrow the educational divide.

Author Contributions: Conceptualization, X.-Y.W.; data curation, X.-Y.W.; formal analysis, G.L.; funding acquisition, X.-Y.W.; investigation, X.-Y.W.; methodology, J.-F.T. and X.-Y.W.; project administration, G.L.; supervision, J.-F.T.; visualization, G.L.; writing-original draft preparation, X.-Y.W.; writing-review and editing, J.-F.T., N.T.T.K., and C.-Y.C. review and edit the study. All authors have read and agreed to the published version of the manuscript.

Funding: The research of this paper is a phased achievement of the general teaching of the 13th Five-Year Plan of the Education Science of Jilin Province, "Investigation of the teaching mode of the construction of high school biological life concepts." The subject number is GH171430. Sincere thanks are given to the sponsor by the authors.

Institutional Review Board Statement: The study was conducted according to the guidelines of the Declaration of Helsinki and approved by the Research Ethic Commitee, Northeast Normal University School of Education (protocal code 2020-12-08 and approval date is 15 December 2020).

Informed Consent Statement: Informed consent was obtained from all subjects involved in the study. Data Availability Statement: Not applicable.

Acknowledgments: The authors also gratefully acknowledge the comments and suggestions of the anonymous reviewers. Part of this paper is a report on the training of the teaching and research team leader of the Department of Biology in Jilin Province in 2018.

Conflicts of Interest: The authors declare no conflict of interest.

\section{References}

1. Lahav, O.; Hagab, N.; Levy, S.T.; Talis, V. Computer-model-based audio and its influence on science learning by people who are blind. Interact. Learn. Environ. 2018, 27, 856-868. [CrossRef]

2. Yen, C.C. How Mobile Learning Can Support Global Student Engagement. 2019. Available online: http://trh.gase.most.ntnu.edu. tw/en/article/content/72 (accessed on 13 November 2019).

3. Nagel, A.S.B.L.; Cronjé, J.C. Read-only participants: A case for student communication in online classes. Interact. Learn. Environ. 2009, 17, 37-51. [CrossRef]

4. Lu, X.; Sun, Y. Application of 5G Technology in Education Informatization. Strateg. Study Chin. Acad. Eng. 2019, 21, 120-128. [CrossRef]

5. Baratè, A.; Haus, G.; Ludovico, L.A.; Pagani, E.; Scarabottolo, N. 5G technology and its application to e-learning. In Proceedings of the 11th annual International Conference on Education and New Learning Technologies, Palma, Spain, 1-3 July 2019; pp. 3457-3466.

6. McGahan, S.J.; Jackson, C.M.; Premer, K. Online Course Quality Assurance: Development of a Quality Checklist. InSight A J. Sch. Teach. 2015, 10, 126-140. [CrossRef]

7. Al-Alwani, A. Evaluation Criterion for Quality Assessment of E-Learning Content. E-Learn. Digit. Media 2014, 11, 532-542. [CrossRef]

8. Rezvania, R.; Vakilinejadb, M. An Evaluation of Translation Quality Assessment Course: Voices from Instructors. Int. Conf. Curr. Trends ELT 2014, 98, 1563-1571. [CrossRef]

9. Doherty, S.; Moorkens, J.; Gaspari, F.; Castilho, S. On Education and Training in Translation Quality Assessment. In Translation Quality Assessment. Machine Translation: Technologies and Applications; Springer: Cham, Switzerland, 2018.

10. Leuverink, K.R.; Aarts, A.M.L. A quality assessment of teacher research. Educ. Action Res. 2019, 27, 758-777. [CrossRef]

11. Evans, C. Class Observation: Participation as a Factor in Training Teachers. J. Educ. Res. 1943, 37, 142-145. [CrossRef] 
12. Codish, D.; Rabin, E.; Ravid, G. User behavior pattern detection in unstructured processes-A learning management system case study. Interact. Learn. Environ. 2019, 27, 699-725. [CrossRef]

13. Xiong, C.; Ge, J.; Wang, Q.; Wang, X. Design and evaluation of a real-time video conferencing environment for support teaching: An attempt to promote equality of K-12 education in China. Interact. Learn. Environ. 2017, 25, 596-609. [CrossRef]

14. Mutlu-Bayraktar, D. Evaluation of change blindness in multimedia learning environment with cognitive process. Interact. Learn. Environ. 2019, 27, 871-894. [CrossRef]

15. Mileham, P. Unlimited Liability and the Military Covenant. J. Mil. Ethics 2010, 9, 23-40. [CrossRef]

16. Ellis, H.; Heppell, S.; Kirriemuir, J.; Krotoski, A.; McFarlane, A. Unlimited Learning. Computer and Video Games in the Learning Landscape; ELSPA (Entertainment and Leisure Software Publishers Association): London, UK, 2006.

17. Saaty, T.L. How to make a decision: The analytic hierarchy process. Eur. J. Oper. Res. 1990, 48, 9-26. [CrossRef]

18. Atanasova Pacemska, P.; Lapevski, M.; Timovski, R. Analytical Hierarchical Process (AHP) method application in the process of selection and evaluation. In Proceedings of the UNITECH-International Scientific Conference, Gabrovo, Bulgaria, 21-22 November 2014; Volume 14, p. II-373-380.

19. Badri, M.A.; Qubaisi, A.A.; Mohaidat, J.; Dhaheri, H.A. An analytic hierarchy process for school quality and inspection: Model development and application. Int. J. Educ. Manage. 2016, 30, 437-459. [CrossRef]

20. Haji, E.E.; Anmani, A.; Harzil, M.E. Using AHP method for educational and vocational guidance. Int. J. Comput. Sci. Inf. Technol. Res. 2017, 9, 9-17. [CrossRef]

21. Looi, C.K.; Sun, D.; Seow, P.; Chia, G. Enacting a technology-based science curriculum across a grade level: The journey of teachers' appropriation. Comput. Educ. 2014, 71, 222-236. [CrossRef]

22. Tseng, J.J.; Cheng, Y.S.; Yeh, H.N. How pre-service English teachers enact TPACK in the context of web-conferencing teaching: A design thinking approach. Comput. Educ. 2019, 128, 171-182. [CrossRef]

23. Owusu, K.A.; Conner, L.; Astall, C. Contextual influences on science teachers' TPACK levels. In Handbook of Research on Teacher Education in the Digital Age; Niess, M.L., Gillow-Wiles, H., Eds.; IGI Global: Hershey, PA, USA, 2015; pp. $307-333$.

24. Bonami, B.; Nemorin, S. Through three levels of abstraction: Towards an ecological framework for making sense of new technologies in education. Educ. Inf. Technol. 2021, 26, 1183-1200. [CrossRef] 